\title{
Storage and Installation of Granite Plugs at the Intersection of the Corridors of the Cheops Pyramid
}

\author{
Alexandr Mikhailovich Yaroschuk \\ Union of Russian Writers, Kemerovo, Russia \\ Email address: \\ kemprosaik@mail.ru \\ To cite this article: \\ Alexandr Mikhailovich Yaroschuk. Storage and Installation of Granite Plugs at the Intersection of the Corridors of the Cheops Pyramid. \\ International Journal of Materials Science and Applications. Vol. 7, No. 2, 2018, pp. 58-61. doi: 10.11648/j.ijmsa.20180702.14
}

Received: February 7, 2018; Accepted: March 5, 2018; Published: March 27, 2018

\begin{abstract}
The article investigates the design of the intersection of the Descending and Ascending Corridors in the pyramid of Cheops. Until now there is no convincing indication of the storage location for the granite plugs, and an explanation of how they were delivered and installed. Also, the question remains, how the builders managed to install them so tightly. Many scientists agree that the granite plugs were stored in the Grand Gallery before being used for jamming the intersection, and then were lowered down the Ascending Corridor to the installation site. The article summarizes the earlier versions of the research. In his version, the author proves that the plugs were never placed in the Grand Gallery. The place of their storage could be the special chamber above the intersection. Only in this case, such a tight blockage of the Ascending Corridor is possible. As a proof of his version, the author provides a diagram of the plug installation and an algorithm for their installation.
\end{abstract}

Keywords: Pyramid of Cheops, Descending Corridor, Ascending Corridor, Intersection, Granite Plug, Big Gallery

\section{Introduction}

One of the mysteries in the great pyramid is the Intersection of the Ascending and Descending corridors [1].

The Arabs broke through the entrance to the great pyramid in search of the tomb of the Pharaoh. They came to the intersection of corridors-Descending and Ascending. He was sealed by granite plugs. The robbers bypassed the tube and out into the Grand gallery [2] Egyptologists it is unclear how the builders of the pyramids have clogged up the Rising channel. Granite square tube weighing more than three tons installed in a very confined space.

Granite stoppers consisted of hard quartz, mica and feldspar. They were the same cubes with sides of 1.2 meters. The weight of each tube with a density of granite $2.6 \mathrm{t} / \mathrm{m} 3$ was 4.5 tons [4].

No one still has not explained how the Builders managed so tightly to install multi-ton tube. They can neither move nor stir [4]. So the question arises - where he kept a tube until their use? Obviously, they were pre-made and delivered to the pyramid. The proof is carved into the rock of the socalled hallways of the tests [4]. They represent an exact copy of the corridor, but with a vertical hole. There were fitted tubes before installation in the pyramid. Egyptologists have proposed many versions of installation tubes. They are complicated, impracticable, and in their implementation impossible to believe. Description of the installation methods of the tubes is in the encyclopedic the book of P. Tompkins a whole Chapter [5]. Two of them present. The French Explorer J. Goyon "put" tube in the Gallery. They were attached with beams. The beam rested in the rack, inserted into the recesses of the ramp. At the right time the tube pulled on the wooden flooring in the Rising channel. Italian researchers Maragioglio V. and C. Rinaldi support this version. Professor L. Borchardt put the cork is also in the Gallery, under the ceiling on the platform of special supports. French Professor J. Bruche and offers a self object. He claims that the tube could not slip down with such minor gap: it was necessary to have the walls as smooth as glass. However, the walls are rough-hewn. 


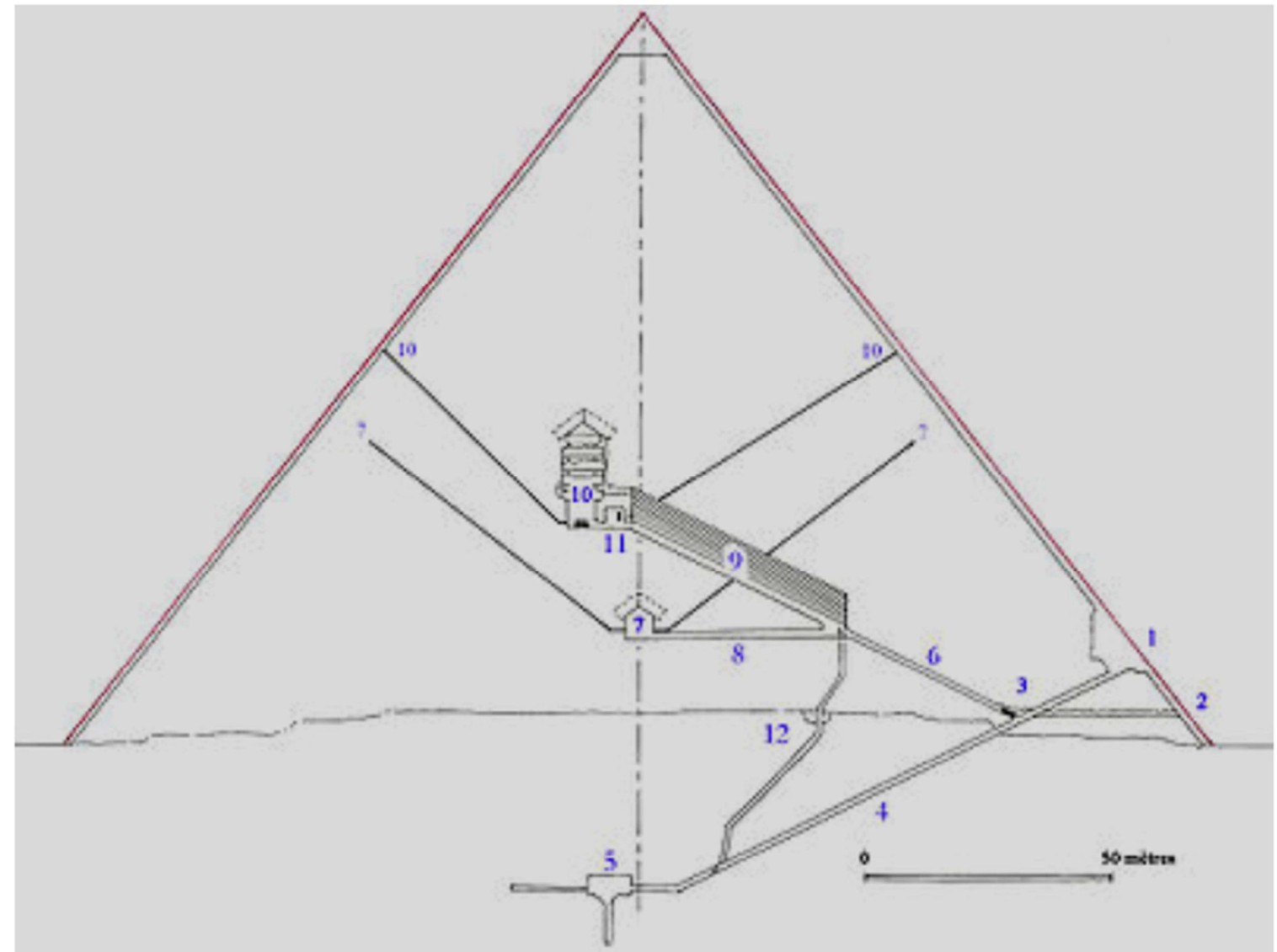

Figure 1. A cross-section of the pyramid of Cheops [3].

1.1. Main entrance; 1.2. Entrance done by al-Maamoun; 1.3. The junction tube and the tunnel of al-Maamoun made of "bypass"; 1.4. The descending corridor; 1.5. Unfinished burial chamber Pit; 1.6. The rising channel; 1.7. The chamber of the Queen with the outgoing "air ducts"; 1.8. The horizontal tunnel; 1.9. Gallery; 1.10. The king's chamber with "air duct"; 1.11. The pre-chamber; 1.12. The grotto

The downward corridor has a length of 105 meters. The cross section of $1.21 \times 1.2$ meters. The angle of $26^{\circ} 26^{\prime}$. The ascending corridor has a length of 40 meters. The cross section of $1.2 \times 1.2$ meters. The angle of elevation is $26^{\circ} 25^{\prime}$. The corridors intersect at a distance of 15 meters from the base of the pyramid.

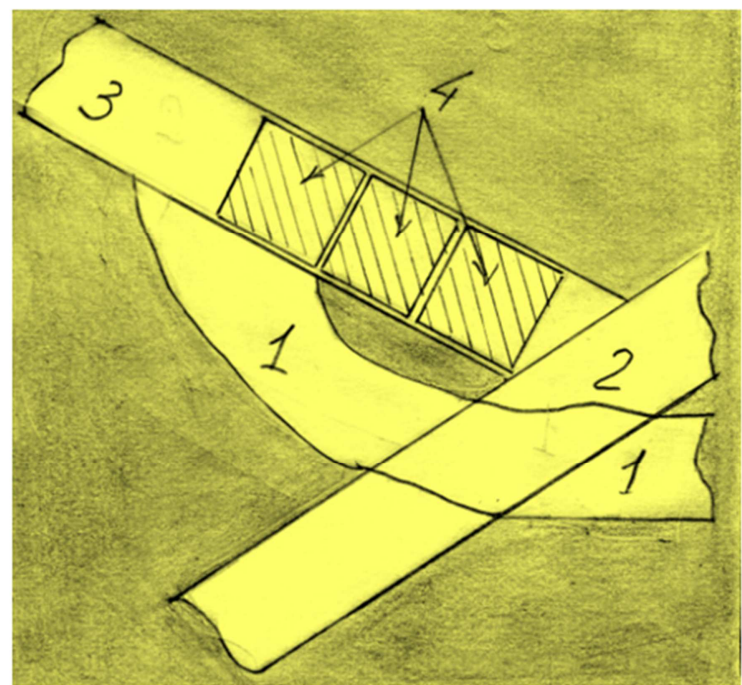

Figure 2. TheIntersection. Figure Author.
Where: 2.1. Entrance, pierced by the Arabs; 2.2. The descending corridor; 2.3. The rising channel; 2.4. Plugs

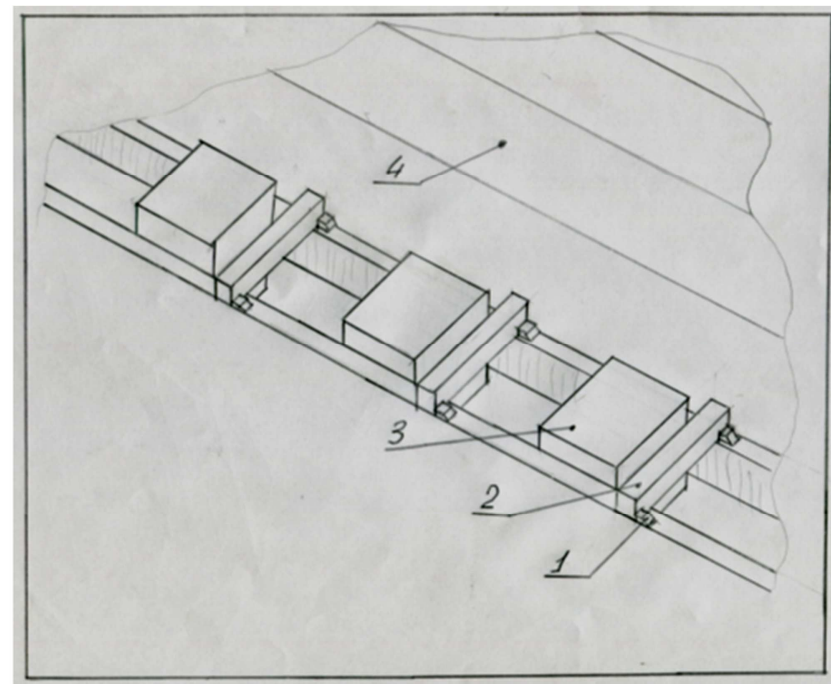

Figure 3. Tube in the Gallery at the J. Goyon [5].

3.1. Bearing in the recess of the ramp

3.2. Support beam

3.3. Granite tube

3.4. Wall oven Gallery 
In addition, it is necessary to provide the required dimensions of the free cross section for the entire length of the Uptrend channel.

It is absolutely impossible to be in the right place all three tubes are tightly plugged passage [4].

When driving on the oiled floor of the Corridor they could develop considerable speed. The obstacle in their way (a narrow corridor) can lead to disaster. Tube could break the blocks that lined the corridor, or deform. Tube could get stuck in the middle of the road. And what to do in this case? To disassemble the pyramid?

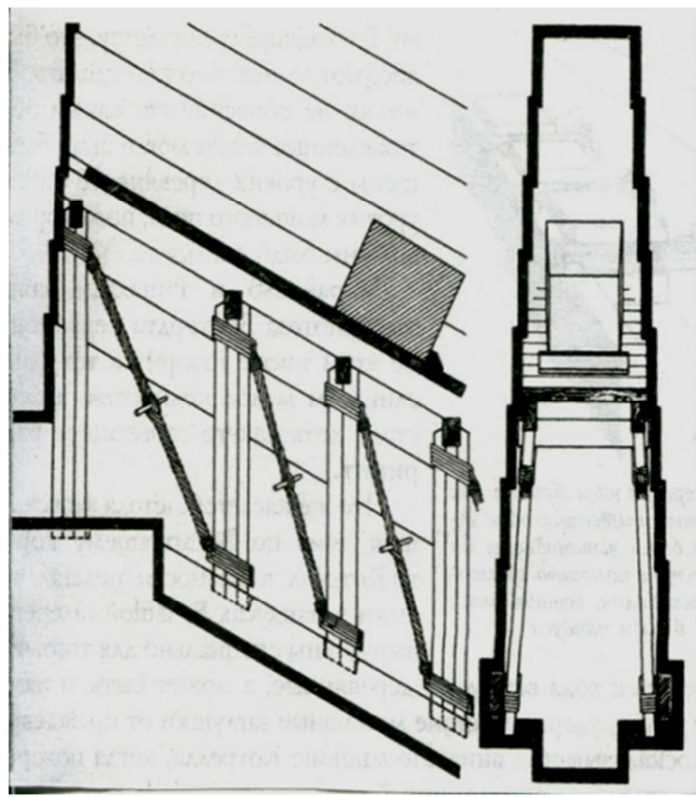

Figure 4. Scheme L. Borchardt [4]. The rise tubes on a special platform to the place of their storage.

The irrationality of placing tubes in the Gallery, where they had been sitting twenty years, is obvious. It excluded the possibility of using it for its intended purpose. Opponents ask the authors of these versions: and where are the mounting wooden beams and a massive deck, which was down the tubes? They do not push through the mine as the evacuation path. They could not evaporate without a trace!

\section{Method}

The author refuted the hypotheses of the XIX century and offered his version by the method of scientific research of the previous works.

The author of the article [5] proved that the dimple on the ramps of the Gallery are designed to block the lifting of the Elevator. According to the author, above the traffic jams, the camera is, which brought traffic jams during construction.

To put such a camera out of the blocks for the builders of the pyramids a breeze. In addition, it saves units time and effort. Without a doubt, the cork down into the corridor through the upper hole from the camera store.

The first solution Stanley top tube and fire brothers from the declining channel. Then Bali brothers, Stanley of the lower tube, leaving the place in Las for can Probe. Further saliva between the Probe binds to the solution, and the probe both racial on top of the third. As a result, the solution to sell and empty (and large man) and provided a heretic.

In this way the builders have provided a tightness triggered portcullis in the pyramid Snefru, but not the solution, and dry plaster applied to the surface portculis $[6,7]$.

Then in the remaining space above the declining channel was inserted into the solution and cover.

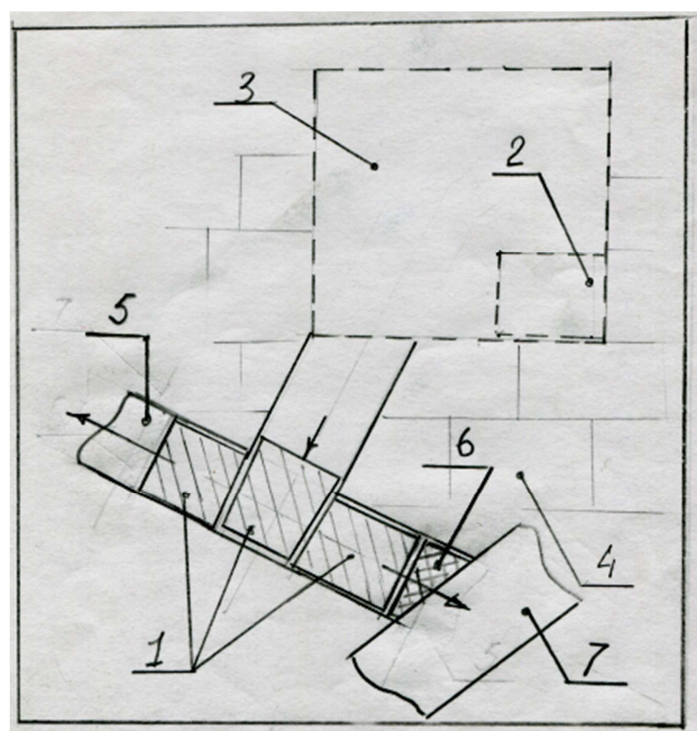

Figure 5. The Intersection. The scheme of the author.

5.1. Tube in the hallway

5.2. Tube in the storage

5.3. Camera storage tubes

5.4. The body of the pyramid

5.5. The rising channel

5.6. Plug

5.7. Declining channel

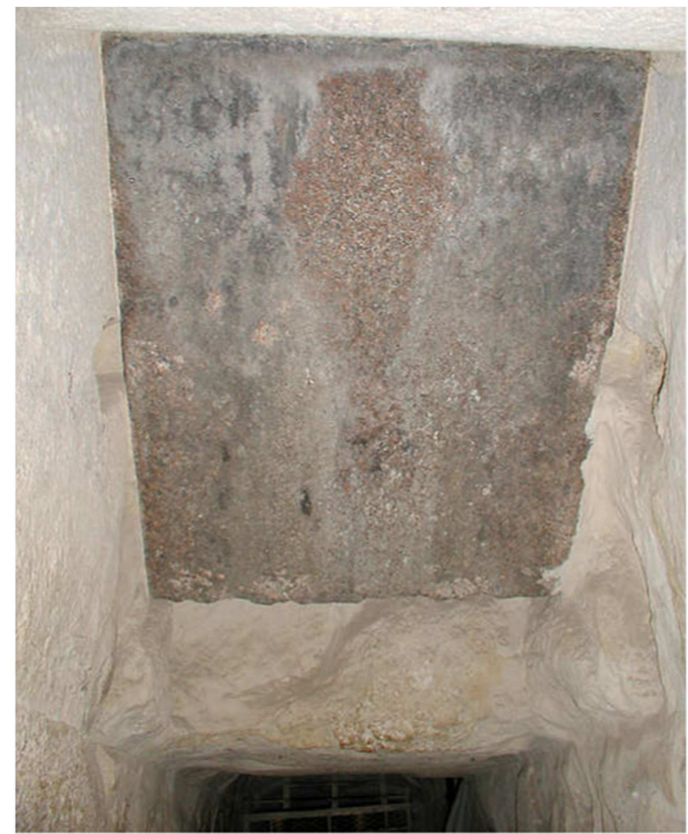

Figure 6. Tube Rising channel [8]. 
She went down under its own weight, when the concussion from the cracked mortar. The researchers can't explain why between the first stopper and the second was grout. Versions of other researchers there should be grease, which was a flat tube. This fact speaks in favor of the version of the author. Please note in the photo. Side in the wall of hollowed-out square recesses under the bar to clamp the lower tube.

\section{Result}

Tubes have the shape of a cube. This is proof that they are descended through the upper hole. Only this form allows you to move them through the manhole, down the hall in all directions without changing orientation in space. A way to drown out the corridor - the most simple, and does not allow to remove the tube from the bottom. Tube is made with a slight wedge, therefore, to pull them out you must knock over the entire height on all sides. Many researchers have expressed the version that the lower blocks under the tubes, the builders installed a specially of the softer limestone, intentionally directing robbers on this way. This is not so. The area of the upper manhole and the traffic, the builders were forced to lay out a more durable material than the body of the pyramid. I am sure, who will open the middle tube, and that detects the manhole, and camera, and other cavities.

Researchers recently did not offer new versions of the installation and storage of granite Plugs $[4,5,6,11,12$, $13]$.

\section{Conclusion}

The author proposed a version of the overlap Uptrend channel is simple, the rationality that is inherent in the builders of ancient Egypt. Is more realistic that anything previously offered.

\section{References}

[1] Nepomnyaschiy N. In the footsteps of giants. Why the tunnels of the great pyramid were laid. When and how? Mode of access: http://sv-scena.ru/Buki/Po-slyedam-vyelikanov. 20.html

[2] Internet, sayt Cheops. The encyclopedia.

[3] Egiptopediya: Entsiklopediya Drevnego Egipta. Rezhim dostupa: egyptopedia.info

[4] Tompkins P. Taynyi Velikoy pyramidyi Heopsa. Zagadki dvuh tyisyacheletiy. M.: Tsentrpoligraf, 2008. $480 \mathrm{~s}$.

[5] Yaroschuk A. Gruzovoy lift pyramidyi Heopsa // News of science: Proceedings of materials the international scientific conference, 30-31 avgusta 2015 g. / red. N. P. Nesgovorova. M.; KarlovyiVaryi. S. $139-156$.

[6] Yaroschuk A. Egipet. Dashur. Lomanaya pyramida Snefru. Verhnyaya kamera - kamera smerti // Vestnik Kemerovskogo gosudarstvennogo universiteta. 2017. №1. S. $80-84$. DOI: 10.21603/2078-8975-2017-1-80-84.

[7] Yaroschuk A. Palach na sluzhbe u mumii. LAMBERT Academic Publishing, 2017.52 s.

[8] Fahri A. DrevniezagadkiFaraonov. M.: Tsentrpolitizdat, 2008. $256 \mathrm{~s}$.

[9] Shalabi A. Ves Egipet. Ot Kaira do Abu-Simbela i Sinay. Florentsiya, 2003.128 s.

[10] Vikipediya Rezhim dostupa: https://ru.wikipedia.org/wiki/Pyramida Heopsa

[11] Henkok Grjem. Sledy Bogov. - M.: Veche, 1999.

[12] Unis D. Otchjot ob jekspedicii v Egipet. 2012 // Isida. Rezhim dostupa: http://isida-project.ucoz.com/forum/31-18-1

[13] Skljarov A. Ju. Piramidy. Zagadki stroitel'stva i naznachenija. 